\title{
The Integrative Optimization by RBF Network and Particle Swarm Optimization
}

\author{
Satoshi Kitayama Member (Kanazawa University, kitagon@t.kanazawa-u.ac.jp) \\ Keiichiro Yasuda Member (Tokyo Metropolitan University, yasuda@eei.metro-u.ac.jp) \\ Koetsu Yamazaki Non-member (Kanazawa University, yamazaki@t.kanazawa-u.ac.jp)
}

Keywords : global optimization, RBF network, particle swarm optimization, response surface

This paper presents the integrative optimization system using the RBF (Radial Basis Function) network and Particle Swarm Optimization (PSO). Recently, many methods for global optimization have been proposed. The objective of these methods is to find a global minimum of non-convex function. However, many function calls are required, in general. We utilize the Response Surface Method (RSM) to approximate function space, in order to reduce the function calls. The RBF network that is one of the neural networks is utilized to approximate the function space. Then PSO is applied to the response surface. The integrative optimization system is shown in Fig.1.

In general, the Gauss function is utilized as the basis function of RBF network. However an important parameter, which is the radius of Gauss function, is involved. The new equation to determine the radius is given as follows:

$$
r=\frac{d_{\max }}{\sqrt{n} \sqrt[n]{m}}
$$

where $r$ denotes the radius. $n$ represents the number of decision variables, and $m$ represents the number of sampling points. $d_{\max }$ denotes the maximum distance between sampling points.

The network output function to handle the constraints is also proposed. This function can be expressed as follows:

$$
y_{i}=A \frac{\alpha_{i}+1}{2}\left(\frac{a_{i}-a_{\min }}{a_{\max }-a_{\min }}+\alpha_{i}\right)+B \frac{\alpha_{i}-1}{2}\left(\frac{f_{\max }-f_{i}}{f_{\max }-f_{\min }}-\alpha_{i}\right)
$$

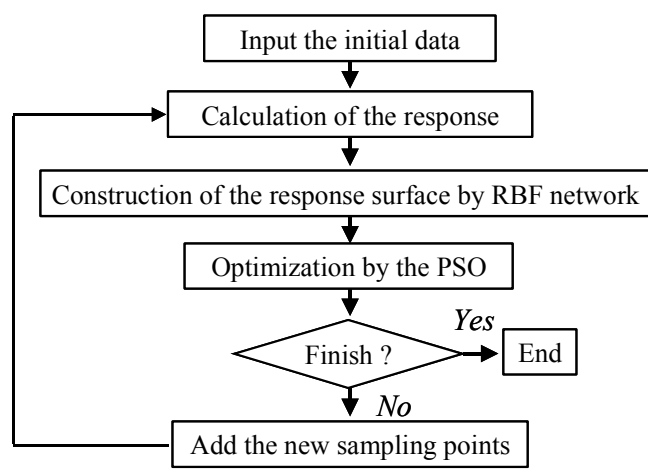

Fig. 1. The integrative optimization system

$$
\begin{aligned}
& g_{j}\left(\boldsymbol{x}_{i}\right) \leq 0 \quad \forall j=1,2, \cdots, \text { ncon } \rightarrow \alpha_{i}=-1 \\
& g_{j}\left(\boldsymbol{x}_{i}\right)>0 \quad \exists j \quad \rightarrow \alpha_{i}=+1 \ldots \ldots \ldots \ldots \ldots \ldots \ldots \ldots \ldots \ldots \ldots \ldots \ldots \ldots \ldots \ldots \ldots \ldots \ldots \ldots \ldots \ldots \ldots \ldots \ldots \ldots \\
& a_{i}=\sum_{j=1}^{n c o n} \max \left[0, g_{j}\left(\boldsymbol{x}_{i}\right)\right]
\end{aligned}
$$

for all sampling points $\boldsymbol{x}_{i} \quad i=1,2, \cdots, p$

where $y_{i}(i=1,2, \cdots, p)$ represents the output of network output function. In Eq. (2), $f_{\max }$ and $f_{\min }$ represent the maximum and minimum value of the objective function at the sampling point in the feasible region, respectively. $\alpha_{i}$ is the parameter to distinguish the feasibility of sampling point $\boldsymbol{x}_{i}(i=1,2, \cdots, p)$. If $\boldsymbol{x}_{i}$ satisfies the feasibility, $\alpha_{i}$ is set as -1 . Otherwise, $\alpha_{i}$ is set as +1. $a_{\max }$ and $a_{\min }$ can be calculated from Eq. (5).

To examine the validity and efficiency of integrative optimization system, the optimum design of tension/compression spring is treated in this research. The decision variables are (1) the wire diameter $d\left(=x_{1}\right),(2)$ the mean coil diameter $D\left(=x_{2}\right)$, and (3) the number of turns of active coil $N\left(=x_{3}\right)$. All decision variables are continuous. The final result is shown in Table 1. From Table 1, the integrative optimization system proposed in this research works well. Especially, we have succeeded the reduction of function calls in comparison with the past researches.

Table 1. Comparison of results

\begin{tabular}{|l|c|c|c|c|c|}
\hline & Arora & Coello & Ray & Hu & $\begin{array}{c}\text { This } \\
\text { research }\end{array}$ \\
\hline$x_{1}(d)$ & 0.053396 & 0.051480 & 0.050417 & 0.051466 & 0.055740 \\
\hline$x_{2}(D)$ & 0.399180 & 0.351661 & 0.321532 & 0.351384 & 0.428503 \\
\hline$x_{3}(N)$ & 9.185400 & 11.63220 & 13.97991 & 11.608659 & 8.971126 \\
\hline$g_{1}(\boldsymbol{x})$ & 0.000019 & -0.002080 & -0.001926 & -0.003336 & -0.018995 \\
\hline$g_{2}(\boldsymbol{x})$ & -0.000018 & -0.000110 & -0.012944 & -0.000110 & -0.061039 \\
\hline$g_{3}(\boldsymbol{x})$ & -4.123832 & -4.026318 & -3.899430 & -4.026318 & -3.752616 \\
\hline$g_{4}(\boldsymbol{x})$ & -0.698283 & -0.732123 & -0.752034 & -0.731324 & -0.677171 \\
\hline$f(\boldsymbol{x})$ & 0.012730 & 0.012705 & 0.013060 & 0.012667 & 0.014606 \\
\hline Fun. calls & $\mathrm{N} / \mathrm{A}$ & 900000 & 1291 & $\mathrm{~N} / \mathrm{A}$ & 86 \\
\hline $\begin{array}{c}\text { Ave. of } \\
f(\boldsymbol{x})\end{array}$ & $\mathrm{N} / \mathrm{A}$ & 0.012769 & 0.013436 & 0.012719 & 0.016771 \\
\hline $\begin{array}{c}\text { Worst of } \\
f(\boldsymbol{x})\end{array}$ & $\mathrm{N} / \mathrm{A}$ & 0.012822 & 0.013580 & $\mathrm{~N} / \mathrm{A}$ & 0.018438 \\
\hline
\end{tabular}




\title{
RBF ネットワークと Particle Swarm Optimization による 統合的最適化
}

\author{
正 員 北山 哲士* 正 員 安田恵一郎** \\ 非会員 山崎 光悦*
}

\begin{abstract}
The Integrative Optimization by RBF Network and Particle Swarm Optimization
Satoshi Kitayama*, Member, Keiichiro Yasuda**, Member, Koetsu Yamazaki*, Non-member
\end{abstract}

This paper presents a method for the integrative optimization system. Recently, many methods for global optimization have been proposed. The objective of these methods is to find a global minimum of non-convex function. However, large numbers of function evaluations are required, in general. We utilize the response surface method to approximate function space to reduce the function evaluations. The response surface method is constructed from sampling points. The RBF Network, which is one of the neural networks, is utilized to approximate the function space. Then Particle Swarm Optimization (PSO) is applied to the response surface. Proposed system consists of three parts. That is, (Part 1) Generation of the sampling points, (Part 2) Construction of response surface by RBF Network, (Part 3) Optimization by PSO. By iterating these three parts, it is expected that the approximate global minimum of non-convex function can be obtained with a few number of function evaluations. Through numerical examples, the effectiveness and validity are examined.

キーワード : 大域的最適化, RBF ネットワーク, Particle Swarm Optimization, 応答曲面

Keywords : global optimization, RBF network, particle swarm optimization, response surface

\section{1. はじめに}

実際の設計現場では，限られた時間で優れた製品を作る 必要がある。優れた製品を作るには，現状の製品を他社製 品と比較・分析し，問題点や課題などを明らかにし，この ような問題点や課題を克服するように製品設計を進めるこ とが必要となる。一方, 近年の急速な最適設計ソフトウェ アの発達を考えれば，これらを活用して設計を行うことは 一つの有力な方針である。多くのソフトウェアは数理計画 法や発見的手法など, 数多くの手法や機能が取り込まれて いるものの，日本の製品設計において，その活用度は低い という極めて興味深い調査報告がなされている ${ }^{(1)}$ 。

文献(1)の報告において, (1)手法やッールを活用すべきか 活用すべきではないかについての判断が系統立てて行われ ていない可能性があること, (2)製品設計において最適化を 行った際の効果は認められていること，が指摘されている

* 金沢大学

干920-1192 金沢市角間町

Kanazawa University

Kakuma-machi, Kanazawa, Ishikawa 920-1192

** 首都大学東京

干192-0397 東京都八王子市南大沢 1-1

Tokyo Metropolitan University

1-1 Minamiosawa, Hachioji-shi, Tokyo 192-0397
ことは注目に值する。この調査結果は, 最適化アルゴリズ ムを開発することは重要であることは認めながらも, むし ろそれらを実務レベルで使いこなせるような統合的な最適 化システムの構築がなされていなことを指摘したものであ る。つまり，モデリングやシミュレーション技術と最適化 技術を有機的に融合・結合した「統合的最適化システム」 の構築が実現できれば，実務レベルにおいて最適化よる大 きな効果が期待できるということを示唆している。

文献(1)において, 特に実験計画法の認知度や活用度が他 の最適化手法や最適設計ソフトウェアと比較して, 群を抜 いている。実験計画法を用いた応答曲面法では, いくつか のサンプル点を直交表に割当て, サンプル点における関数 の応答值から関数空間を近似する応答曲面を作成し，その 応答曲面に対して最適化手法を適用するため ${ }^{(2)}$, 実質的な関 数評価回数はサンプル点の数だけであり, 計算コストは極 めて少ない。また，実務レベルの最適設計では関数形が設 計変数の陽な形で表現できないことばかりではなく，実験 データそのものから最適設計を行うことも多く，このよう な設計問題に対しては応答曲面法によるアプローチは極め て有効である。さらに近年, 詳細な解析モデルに基づく衝 突解析や数值流体解析などが実務レベルの製品設計に利用 
されるようになってきている。しかしながら，これらの解 析に必要な計算負荷の重さを踏まえれば, 従来の数理計画 法などを構築された詳細モデルに直接的に適用して最適解 を求めることは，計算コストの観点から現実的ではない。

上述のように，実験計画法による応答曲面法は非常に有 効であるように思われるが，局所的最適解が多数あるよう な多峰性関数を扱う場合, 基本的には関数空間を二次多項 式で近似するため, 大域的最適解とは異なる局所的最適解 一収束するなどの問題が含まれる。つまり, 実験計画法に 基づく応答曲面法の有効となるのは, 比較的非線形性の弱 い対象に限定されると考えるのが妥当であろう。

多項式を用いて近似することも可能であるが，その際に はいくつかの注意が必要である(3)。また有制約最適化問題の 場合, 制約条件は基本的に目的関数とは個別に近似するた め, 近似関数に対し, 各種最適化手法を適用しても, 得ら れる近似解が実行可能領域内にないという大きな問題が起 こり得る。このような場合は, (1)過去のサンプル点情報な どをすべて破棄して再びサンプル点を変更し, 応答曲面を 再構築して最適化を行うといったことを繰り返す, (2)制約 条件の近似精度を向上させるために，多くのサンプル点を 配置する，などのことが行われるが，このようなアプロー チは，計算コストが極めて少ないという応答曲面法の本来 の利点を活かすことができなくなる。

一方, 多峰性関数を近似する手法として, Kriging 法 ${ }^{(4)}$ RBF (Radial Basis Function) ネットワークによる関数近似 ${ }^{(5)}$ などが挙げられる。RBF ネットワークは Kriging 法よりも計 算が簡素であり，かつ計算量が少ない。また，いくつかの 多峰性関数を対象とした数值実験の結果, 関数近似の精度 が他の近似手法よりも優れているという報告もなされてい る(6)。さらに近年の研究動向を考えれば(7), RBF ネットワー クを応答曲面の作成に用いることは重要であると考える。 ただし, RBF ネットワークで問題となるのは, 基底関数内 に含まれるパラメータ (半径) の設定である。このパラメ 一タを適切に設定しなければ, 関数の近似精度は極めて悪 化する。さらに Kriging 法と異なり, 関数の近似精度を向上 させるようなサンプル点の配置に関する指針がないなどの 解決すべきいくつかの課題がある。

ここで文献( 1 )で指摘された点を踏まえ, RBF ネットワー クを応答曲面作成に用いた際の最適化に関する課題につい てまとめておこう。

（P1）過去の探索履歴情報をすべて活用した，一般的かつ柔 軟な統合的最適化システムの構築。すなわち実験計画法 に基づく応答曲面法のように, 応答曲面の最適解が実行 可能領域内になかった場合も, サンプル点とその忘答值,

\footnotetext{
†本論文で近似（局所的もしくは大域的）最適解とは，応答曲面の 最適解を指し, 単一目的関数の最小化（もしくは最大化）問題にお いて, 厳密な局所的もしくは大域的最適解ではないものの, その解 で目的関数を評価した際でも十分に満足できる解を意味する。最適 満足解と捉えることも可能であるが，最適満足解という言葉は文献 (8)で用いられているため, 本論文では近似（局所的もしくは大域 的）最適解と呼ぶことにする。
}

もしくは実験データ等すべての情報を活用すること。 (P2) 基底関数内に含まれるパラメータ設定に関する一つの 指針の提案。すなわち, パラメータの推奨式の提案。 (P3) 有制約最適化問題を対象とする際の制約条件の取扱い に対する明確な記述。

(P4) 大域的最適化に合致したサンプル点の追加方法。 そこで本論文では，上記の課題について汎用的かつ統合 的最適化システムの提案を行う。 RBF ネットワークで作成 された応答曲面の大域的最適解探索には, メタヒューリス ティクスの一つである Particle Swarm Optimization (PSO) ${ }^{(14)}$ を適用する。(P2)に関しては過去に提案されているパラメー 夕決定式の検討を行い, そこから得られた知見を基に新た なパラメータ決定の推奨式を提案する。また(P3)に関しては ネットワーク出力関数と称する, サンプル点の実行可能性 の有無を判別する関数を提案する。

さらに(P4)に関しては, 近似最適解 ${ }^{\dagger}$ の精度向上を狙いつ つ, 局所的最適解へ陥ることを防ぐようなサンプル点配置 方法を提案する。応答曲面法を活用した実務レベルでの最 適設計では, 近似大域的最適解が得られれば問題はないが, 仮に近似大域的最適解が得られなくとも, 次善の近似局所 的最適解が少ないサンプル点数や実験回数から得られるこ とは実務レベルで大きな意義を持つため，このようなサン プル点配置方法は重要である。数值計算例を通じて提案す る統合的最適化システムの有効性を検討する。

\section{2. 本論文で対象とする問題とシステムの概要}

$\langle 2 \cdot 1\rangle$ 問題設定 本論文では以下の問題を対象とす る。

$$
\begin{aligned}
& f(\boldsymbol{x}) \rightarrow \min \\
& x_{i}^{L} \leq x_{i} \leq x_{i}^{U} \quad i=1,2, \cdots, n \cdots \\
& g_{j}(\boldsymbol{x}) \leq 0 \quad j=1,2, \cdots, n c o n
\end{aligned}
$$

(1)式は多峰性を許容した最小化すべき目的関数であり, $\boldsymbol{x}$ は設計変数ベクトルである。(2)式の $x_{i}^{L}$ と $x_{i}^{U}$ はそれぞれ

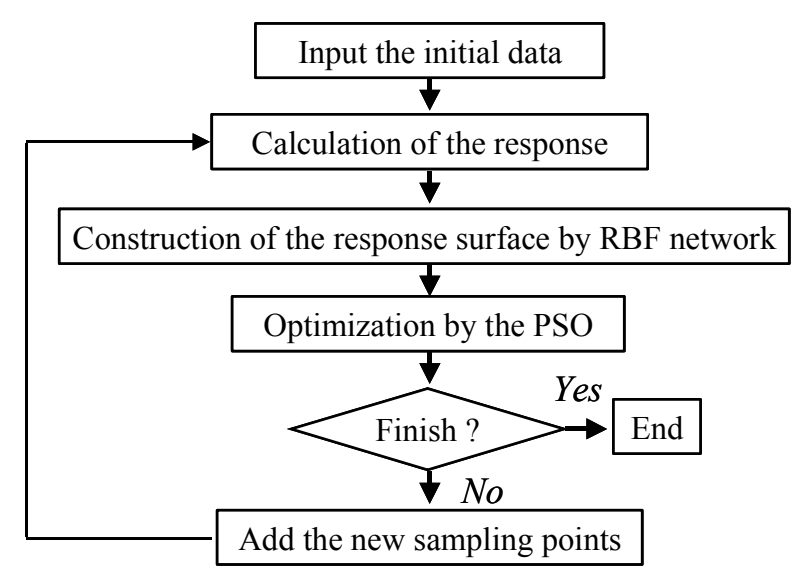

図 1 提案するシステムの概要

Fig. 1. Overview of proposed system 
設計変数ベクトルに直接的に課せられる下限值および上限 值であり, 側面制約条件と呼ばれ, $n$ は設計変数の数を表す。 また $g_{j}(\boldsymbol{x})$ は挙動制約条件であり, ncon はその数を表す。 以下では挙動制約条件のみを単に制約条件と呼ぶことにす る。

〈2·2〉 システムの概要 本論文で提案する統合的最 適化システムの概要を図 1 に示す。提案するシステムは, 図 1 に示すように, サンプル点から解析シミュレーション や実験により応答值を求め, それから RBF ネットワークに より応答曲面を構築し, 応答曲面の大域的最適解を探索す るために PSO を適用する。上記のことを繰り返すことによ り, 与えられた問題の近似最適解を, 可能な限り少ないサ ンプル点数や実験回数で求めるシステムである。終了条件 としては様々なものが考えられるが，本論文で提案する統 合的最適化システムでは, サンプル点の数が最大サンプル 点数に到達した時点で, システムの繰り返しが終了するよ うにしている。以降，3 章において， RBF ネットワークを用 いた応答曲面作成方法を記述し，4 章において，応答曲面の 最適解を求める PSO について説明する。5 章において, 制 約条件を考慮したサンプル点の配置方法について解説す る。

\section{RBF ネットワーク}

$\mathrm{RBF}$ ネットワークはフィードフォワード型の 3 層型のネ ットワークである ${ }^{(9)}$ 。中間層素子数を $m$, 中間層と出力層の 重みを $w_{i}$, ネットワークの出力を $O(\boldsymbol{x})$ とすると, ネットワ ークの出力は

$$
O(\boldsymbol{x})=\sum_{j=1}^{m} w_{j} h_{j}(\boldsymbol{x})
$$

で与えられる。(4)式中において $h_{j}(\boldsymbol{x})$ は基底関数を表し， 一般に中間層の非線形出力関数に次式のガウス関数が用い られている。

$$
h_{j}(\boldsymbol{x})=\exp \left(-\frac{\left(\boldsymbol{x}-\boldsymbol{x}_{j}\right)^{T}\left(\boldsymbol{x}-\boldsymbol{x}_{j}\right)}{r_{j}^{2}}\right)
$$

(5)式において， $\boldsymbol{x}_{j}$ と $r_{j}$ はそれぞれ $j$ 番目の基底関数の中 心と半径である ${ }^{\dagger}$ RBF ネットワークはガウス関数の重补合 わせにより関数を近似する。図 2 左に二変数の場合のガウ ス関数, 同図右に応答曲面の様子を示す。

〈3・1〉 RBF ネットワークにおける学習 RBF ネット ワークにおける学習用データ $\boldsymbol{x}_{i}$ と対になる教師データを $y_{i}$

${ }^{\dagger}(5)$ 式は, サンプル点 $\boldsymbol{x}_{j}$ の上に基底関数の中心を置くことを意味 している。一般的に表現するのであれば,

$$
h_{j}(\boldsymbol{x})=\exp \left(-\frac{\left(\boldsymbol{x}-\boldsymbol{c}_{j}\right)^{T}\left(\boldsymbol{x}-\boldsymbol{c}_{j}\right)}{r_{j}^{2}}\right)
$$

となり, $\boldsymbol{c}_{j}$ が基底関数の中心となる。基底関数の中心も応答曲面の 精度に影響を与えるが，応答曲面の精度自体は，基底関数の中心の 影響よりも，半径の影響が大きいことが知られているため，本論文 では，一般的に広く用いられている方法，才なわち，基底関数の中 心をサンプル点に置く方法を用いて, 半径の決定について議論を進 めるものとする。
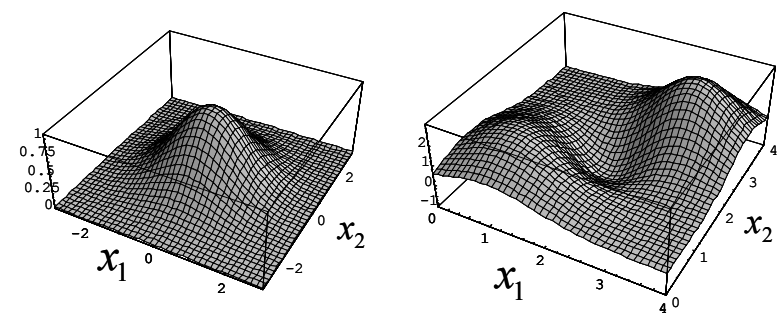

図2 ガウス関数と応答曲面の様子

Fig. 2. Gauss function and response surface

$(i=1,2, \cdots, p)$ とする。このとき, ネットワークの出力值と 教師データの誤差の二乗和を考え, さらに一部の素子だけ が過剰に反応するのを避け，ノイズの影響を出来る限り小 さくするため, 重みに対する抑制項を加えた次式で定義さ れるエネルギ $E$ を最小にする。

$$
E=\sum_{i=1}^{p}\left(y_{i}-O\left(\boldsymbol{x}_{i}\right)\right)^{2}+\sum_{j=1}^{m} \lambda_{j} w_{j}^{2} \rightarrow \min
$$

( 6 )式中の $\lambda_{j}$ は, Weight Decay と呼ばれるパラメータであ り, $\lambda_{j}=1.0 \times 10^{-2}$ 程度の小さな值が推奨されている(10)。 $\mathrm{RBF}$ ネットワークの学習とは, (6)式を満足するように, 重みべ クトル $\boldsymbol{w}$

$$
\boldsymbol{w}=\left(w_{1}, w_{2}, \cdots, w_{m}\right)^{T}
$$

を決定することである。ここで，次の行列を定義する。

$$
\begin{aligned}
H & =\left[\begin{array}{cccc}
h_{1}\left(\boldsymbol{x}_{1}\right) & h_{2}\left(\boldsymbol{x}_{1}\right) & \cdots & h_{m}\left(\boldsymbol{x}_{1}\right) \\
h_{1}\left(\boldsymbol{x}_{2}\right) & h_{2}\left(\boldsymbol{x}_{2}\right) & \cdots & h_{m}\left(\boldsymbol{x}_{2}\right) \\
\vdots & \vdots & \ddots & \vdots \\
h_{1}\left(\boldsymbol{x}_{p}\right) & h_{2}\left(\boldsymbol{x}_{p}\right) & \cdots & h_{m}\left(\boldsymbol{x}_{p}\right)
\end{array}\right] \cdots \\
\boldsymbol{\Lambda} & =\left[\begin{array}{cccc}
\lambda_{1} & 0 & \cdots & 0 \\
0 & \lambda_{2} & \cdots & 0 \\
\vdots & \vdots & \ddots & \vdots \\
0 & 0 & 0 & \lambda_{m}
\end{array}\right] \\
\boldsymbol{y} & =\left(y_{1}, y_{2}, \cdots, y_{p}\right)^{T} \cdots \cdots \cdots \cdots \cdots \cdots \cdots \cdots \cdots \cdots \cdots \cdots \cdots \cdots \cdots \cdots \cdots \cdots \cdots \cdots \cdots \cdots \cdots \cdots
\end{aligned}
$$

( 6 )式のエネルギ最小化より, 最終的に( 7 )式の重みは,

$$
\boldsymbol{w}=\left(\boldsymbol{H}^{T} \boldsymbol{H}+\boldsymbol{\Lambda}\right)^{-1} \boldsymbol{H}^{T} \boldsymbol{y}
$$

と表すことができる。さらに(11)式において

$$
\boldsymbol{A}=\boldsymbol{H}^{T} \boldsymbol{H}+\boldsymbol{\Lambda}
$$

とおけば, RBF ネットワークの学習とは， $\boldsymbol{A}^{-1}$ を求めること に帰着される。

このように RBF ネットワークの学習は, 基底関数の中心 と半径を固定すれば，単に逆行列を求める問題に帰着でき るので，学習は非常に早いという特徴を有している。（半径 やパラメータ $\lambda_{j}$ についても最小化するという考えに基づ き, 最適な半径や $\lambda_{j}$ の值を勾配によって求めることも可能 であるが，このときはRBF ネットワークの学習が単に逆行 列の計算では済まなくなり，計算も複雑になる ${ }^{(11)}$ 。)

さらにその性能を特徵付けるものとして, 追加学習と忘 
却が存在する。関数近似の手法としてよく知られた階層型 ニューラルネットワークと, その学習法として誤差逆伝播 法を用いた場合，一般にサンプル点が追加されるたびにす ベてのサンプル点を用いた学習（非線形最適化）を再度実 行しなければならないが, RBF ネットワークの場合は, 単 純に行列計算のみで学習できるという利点を有しているた め, 高速な追加学習が可能である。サンプル点の追加及び 忘却についての詳細は文献(12)を参照されたい。

〈3·2〉 サンプル点の追加の意義サンプル点を追加 するということは, 最適化の過程で新しく得られたデータ を追加することで, ネットワークの精度, すなわち応答曲 面の精度の向上を狙うことを意味し, はじめから必要以上 のサンプル点を用意する必要がないという点において意義 が大きい。

〈3.3〉 基底関数の追加の意義 基底関数を追加は, 初期的に与えた基底関数の数で応答曲面の精度が十分でな いと判断される場合に行われる。新しい基底関数に適切な 追加により, 最適化すべき対象に応じた精度の高い応答曲 面を適応的に形成できる可能性があるという点において意 義が大きい。

$\langle 3 \cdot 4\rangle$ 基底関数の半径式ついて 基底関数の半径 は，応答曲面の精度に影響を与える重要なパラメータであ る。基底関数に一律な半径を与える方法がいくつか提案さ れている(10)(13)。著者らが行ったいくつかの数值実験によれ ば，文献(10)で提案されている半径式を用いた場合, 低次元 の場合には比較的良好な近似最適解を得ることができた が, 次元が増加した場合には近似最適解を得ることが困難 となることを検証している。そこで本論文では，文献(10) で提案されている半径式を検討することにより，新たな半 径式を提案する。

文献(10)で提案されている半径式は次式で表される。

$$
r=\frac{d_{\max }}{\sqrt[n]{m n}}
$$

(13)式において， $d_{\max }$ はサンプル点間の最大距離であり, $m$ はサンプル点数を表している。すなわち, 中間層素子数 とサンプル点数を同一としている。また，すべての基底関 数に対して一律な半径值を適用している。

ここで水準数を $K$ とし, サンプル点を等閒隔 $\Delta d$ に配置し た全数組合せ実験計画を考える。このときサンプル点間の 最大距離は

$$
d_{\max }=\sqrt{n}(K-1) \Delta d
$$

となる。二次元の場合における上述のサンプル点の配置を 図 3 に示す。

このとき, 総サンプル点数 $m$ と水準数 $K$ の関係は $m=K^{n}$

で与えられるため，(14)式および(15)を(13)式に代入すると

$$
r=\frac{d_{\max }}{\sqrt[n]{n m}}=\frac{\sqrt{n}(K-1) \Delta d}{\sqrt[n]{n K^{n}}}=\frac{\sqrt{n}}{\sqrt[n]{n}}\left(1-\frac{1}{K}\right) \Delta d
$$

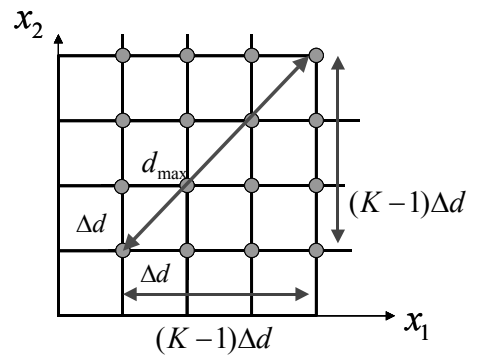

図 3 二次元におけるサンプル点の配置

Fig. 3. Sampling distribution in two dimensions

が得られる。ここで $r$ と $\Delta d$ の比を考えると，(16)式は次の ように変形できる。

$$
\frac{r}{\Delta d}=n^{\frac{n-2}{2 n}}\left(1-\frac{1}{K}\right)
$$

(17)式において $K \rightarrow \infty$ とする。これは関数空間内に無限 のサンプル点を等間隔に配置するということを意味してお り，理想的なサンプル点配置である。このとき， $n=1, n=2$ のときはある值（すなわち 1）へ収束するが, $n \geq 3$ となっ たとき, $n$ の值に応じて個別の值に収束することが判る。す なわち，(13)式を用いた場合に次元が増加するにつれて近似 最適解を得ることが困難でとなった理由の一つとして, 次 元の増加とともに, $r$ と $\Delta d$ の比が個別の值に収束するとい うことが考えられる。

そこで(13)式および今までの議論から得られた知見を基 に, 近似最適解を得るための半径式の十分条件を挙げてみ ると次のようになると思われる。

(R1) 設計変数の数, 寸なわち次元を考慮できること。

(R2) サンプル点の数を考慮できること。

(R3) サンプル点間の距離を考慮できること。

(R4) サンプル点数の増加に伴い, 次元の大きさに依存せ ず，ある同じ值に収束すること。

これらの項目を満足する式として, 本論文では以下の半 径式を提案する。

$$
r=\frac{d_{\max }}{\sqrt{n} \sqrt[n]{m}}
$$

$\mathrm{RBF}$ ネットワークによる応答曲面は図 2 に示した通り, 局所的連続型多峰性関数となるため, その大域的最適解探 索にはPSO を適用する。

\section{Particle Swarm Optimization}

PSO は, 個々の探索点 (Particle) が持つ最良解情報 ( p-best) と, その探索点から構成される集団 (Swarm) が持つ最適解 情報（g-best）を過去の探索履歴情報として活用することで, 連続変数の多峰性関数の近似大域的最適解を求める手法で ある(14)。PSO では各探索点が「位置」と「速度」を持ち, 各探索点の位置と速度を探索履歴情報を用いて更新しなが ら, 近似大域的最適解の探索を行う。以下の記述では, $t$ 回 目の探索における探索点 $d$ の位置を $\boldsymbol{x}_{d}^{t}$, 速度を $\boldsymbol{v}_{d}^{t}$ とする。 また $\boldsymbol{p}_{d}^{t}$ は探索点 $d$ が $t$ 回目までの探索において探索した最 
良解 (p-best) を表し， $\boldsymbol{p}_{g}$ は $t$ 回目までの探索において得ら れた群れ全体の最良解 ( $g$-best) を表す。

以下では基礎的なアルゴリズムのみを示す。詳細は文献 (14)を参照されたい。

\section{〈4·1〉＼cjkstart基本アルゴリズム}

(STEP1) 探索点数, 最大探索回数を決める。 $t=1$ とする。

（STEP2）各探索点に対して，ランダムに初期位置 $\boldsymbol{x}_{d}^{t}$ と初 期速度 $\boldsymbol{v}_{d}^{t}$ を決める。

（STEP3）各探索点に対して，関数值を計算する。

(STEP4） $\boldsymbol{p}_{d}^{t}$ と $\boldsymbol{p}_{g}$ を求める。

（STEP5）各探索点の位置と速度を次式により更新する。

$$
\begin{aligned}
& \boldsymbol{x}_{d}^{t+1}=\boldsymbol{x}_{d}^{t}+\boldsymbol{v}_{d}^{t+1} \\
& \boldsymbol{v}_{d}^{t+1}=w \boldsymbol{v}_{d}^{t}+c_{1} r_{1}\left(\boldsymbol{p}_{d}^{t}-\boldsymbol{x}_{d}^{t}\right)+c_{2} r_{2}\left(\boldsymbol{p}_{g}-\boldsymbol{x}_{d}^{t}\right)
\end{aligned}
$$

なお(19)式において， $r_{1}$ と $r_{2}$ は[0,1]の乱数であり，射影され た直交座標軸ごとに異なる乱数を用いる。また， $c_{1}$ と $c_{2}$ は パラメータであり，本論文では，

$$
c_{1}=c_{2}=2
$$

とした。また $w$ は慣性項と呼ばれるもので, 次式に従い探 索回数 $t$ に応じて線形に減少するように設定した。

$$
w=w_{\max }-\frac{w_{\max }-w_{\min }}{t_{\text {max }}} \times t
$$

(21)式中の $w_{\max }$ と $w_{\min }$ は慣性項の最大值と最小值であり, 本論文では $w_{\max }=0.9, w_{\min }=0.4$ とした。

（STEP6）探索回数 $t$ が最大探索回数以下なら $t=t+1$ とし て，STEP3 へ戻る。そうでなければ，探索を終了する。

\section{5. サンプル点の配置とネットワーク出カ関数}

応答曲面法を用いた最適化において，重要な要素の一つ として, サンプル点の配置方法がある。理想的には関数空 間内にサンプル点を等間隔に配置することが望ましいが， (15)式からも分かるように, このような配置法では次元の増 加に伴い極めて多くのサンプル点を必要とする。少ないサ ンプル点数で近似最適解を得るためには, 応答曲面の最適 解近傍に多くのサンプル点を配置して精度の向上をはかる 一方で，局所的最適解へ陥らないようサンプル点の疎な部 分にもサンプル点を適切に配置する必要がある。さらに疎 密がなくなるよう工夫することが望ましい。そこで本論文 では制約条件を考慮した以下のようなサンプル点の配置方 法を提案する。

$\langle 5 \cdot 1\rangle$ 応答曲面の最適解近傍の作成 応答曲面の最 適解 $\tilde{\boldsymbol{x}}=\left(\tilde{x}_{1}, \tilde{x}_{2}, \cdots, \tilde{x}_{n}\right)^{T}$ 周辺の関数の近似精度を向上させ，近 似最適解を得るために $\tilde{\boldsymbol{x}}$ の近傍を作成し，その近傍内にサ ンプル点を追加する。さらに多峰性関数を対象とする場合 は， $\tilde{\boldsymbol{x}}$ の近傍外にもサンプル点を追加することにより，局 所的最適解への捕捉を防ぐ必要がある。本論文では各設計 変数の側面制約条件を利用して近傍を作成する。具体的に は， $\tilde{\boldsymbol{x}}$ を中心として，以下の式により近傍の大きさ $l_{i}$ を決 め, $\tilde{\boldsymbol{x}}$ の近傍を作成する。

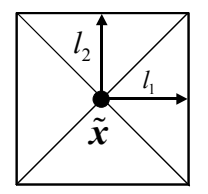

図 4 応答曲面の最適解近傍

Fig. 4. The neighborhood of optimum of response surface

$$
l_{i}=\frac{1}{\text { count }+1}\left(x_{i}^{U}-x_{i}^{L}\right)
$$

(22)式中の count はパラメータであり, 1 以上の整数とす る。count 值の初期值は許容される計算コストや実験回数に より, 設計者が任意に変更できるパラメータである。二次 元の場合の例を図 4 に示す。

〈5·2〉 サンプル点の追加 応答曲面を $k$ 回作成した とき, $k$ 回目の応答曲面の最適解を $\tilde{\boldsymbol{x}}^{k}$ とし, 過去の応答曲 面の最適解で, 最も良い目的関数值を与えるものを $\tilde{\boldsymbol{x}}_{G}$ とす る。制約条件を満足するかどうかが判定された後, 制約条 件を満足している場合については， $f\left(\tilde{\boldsymbol{x}}^{k}\right)<f\left(\tilde{\boldsymbol{x}}_{G}\right)$ は検討さ れることになる。このとき, 以下の 4 つの場合を考えなが ら，サンプル点を追加する。以下では， $\tilde{\boldsymbol{x}}_{G}$ の近傍を $R_{G}, \tilde{\boldsymbol{x}}^{k}$ の近傍を $R_{L}$ とする。また図 5 内で $\tilde{\boldsymbol{x}}_{G}$ をで， $\tilde{\boldsymbol{x}}^{k}$ をで表 于。

CASE 1：(図 5(a)） $\tilde{\boldsymbol{x}}^{k}$ が制約条件を満足しないが， $R_{G}$ 内 に存在する場合 : このときは

count $=$ count +1

として近傍 $R_{G}$ を変更する。そして, 変更された $R_{G}$ 内と $R_{G}$ の外でサンプル点が疎な領域にそれぞれ, サンプル点をラ ンダムに $q$ 個追加する。これは $\tilde{\boldsymbol{x}}_{G}$ の精度向上と局所的最適 解への捕捉を防ぐことを期待して行う。

CASE 2：(図 5(b)） $\tilde{\boldsymbol{x}}^{k}$ が制約条件を満足せず，かつ $R_{G}$ 内に存在しない場合:このときは $R_{G}$ はそのままにしておき, $R_{G}$ 内と $R_{G}$ の外でサンプル点が疎な領域にそれぞれ, サンプ ル点をランダムに $q$ 個追加する。これはこの時点で近似最 適解を求めることが期待できないため, サンプル点の追加 により $\tilde{\boldsymbol{x}}_{G}$ の精度向上を狙う。

CASE 3 : (図 5(c)） $\tilde{\boldsymbol{x}}^{k}$ が制約条件を満足し, かつ $R_{G}$ 内に 存在する場合：このときは $R_{G}$ の近傍を(23)式により変更し, 変更した $R_{G}$ 内と $R_{G}$ の外でサンプル点が疎な領域にそれぞ れ，サンプル点をランダムに $q$ 個追加する。これは $\tilde{\boldsymbol{x}}_{G}$ の精 度向上と局所的最適解への捕捉を防ぐことを期待して行 う。

CASE 4：（図 5(d)） $\tilde{\boldsymbol{x}}^{k}$ が制約条件を満足するが， $R_{G}$ 内に 存在しない場合：このきは $R_{G}$ の大きさはそのままにしてお き，新たに $\tilde{\boldsymbol{x}}^{k}$ の近傍 $R_{L}$ を作成する。そして $R_{G}$ 内と $R_{L}$ 内に それぞれ，サンプル点をランダムに $q$ 個追加する。これは たとえ近似大域的最適解が得られなくとも, 近似局所的最 適解を得ることを期待して行う。

本論文で提案するサンプル点配置方法は大域的探索と局 所的探索を組み合わせたものであり，たとえ近似大域的最 適解を得られなくとも, 近似局所的最適解が得られればよ 


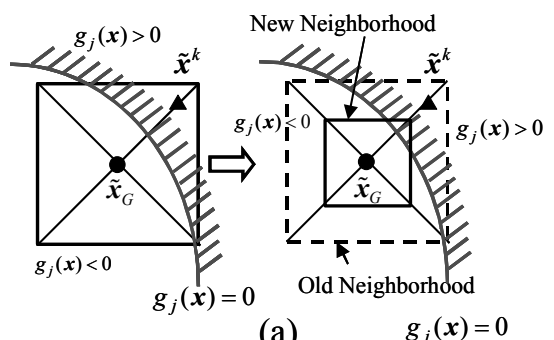

(a)

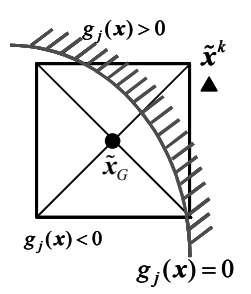

(b)

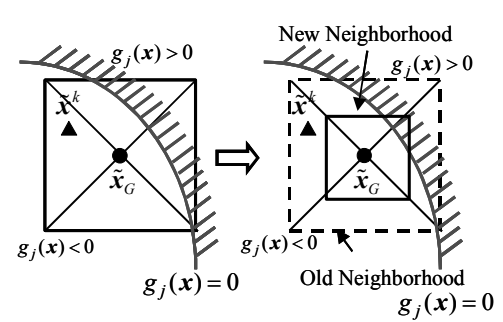

(c)

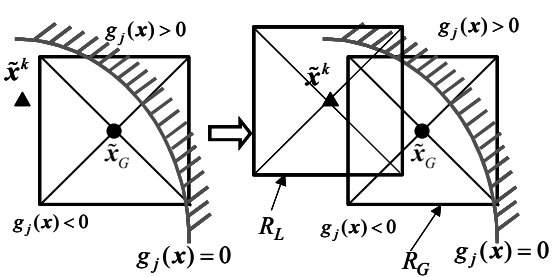

(d)

図 5 サンプル点配置の方法

Fig. 5. Sampling distribution on proposed method

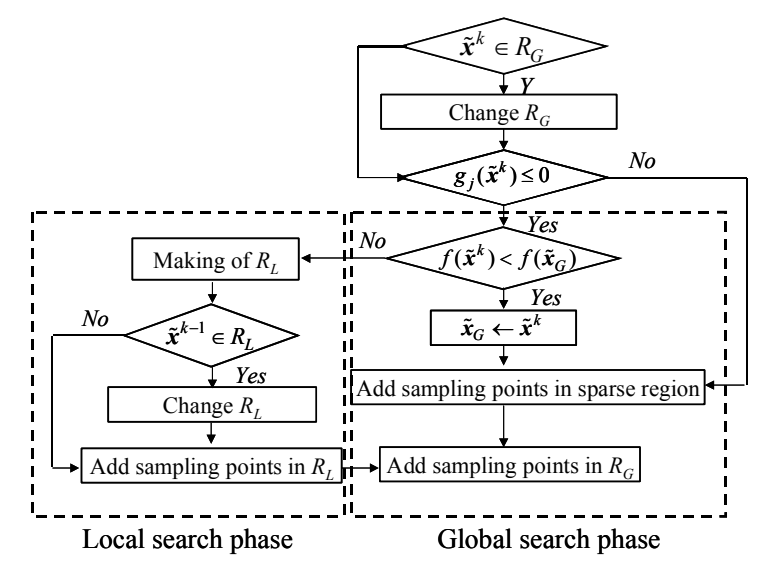

図 6 サンプル点配置のアルゴリズム

Fig. 6. The algorithm for sampling distribution

いという立場に立つものである。また, $R_{L}$ についても CASE1 〜CASE4 の場合を考えるので，サンプル点配置に関するア ルゴリズムは図 6 のようになる。

〈5·3〉 疎な領域の判定 サンプル点の疎な領域の判 断は，次のようにして行う。

(1) $R_{G}$ 外にランダムに多数の点を発生。

（2）既存のサンプル点とランダムに発生させた点の距 離の総和を計算。

（3）距離の総和が最大となる点を疎な領域の点とする。
これを一定数 $q$ になるまで繰り返す。

〈5・4〉 サンプル点の追加数 サンプル点追加方法に おいて, 応答曲面の近傍内外にサンプル点を少しずつ追加 寸ると, 応答曲面は凹凸の極めて激しいものとなり, 結果 的に近似最適解を得ることが困難となる場合が起こりう る。そのため, 近似最適解を得るためには, 応答曲面の近 傍内外に追加するサンプル点は複数個であることが望まし い。そこで，与えられた問題の設計変数の数に応じて, 以 下のようにサンプル点を追加する数 $q$ を決めた。

$$
q=\operatorname{int}(n / 2)
$$

なお，(24)式の int は四捨五入の関数を表す。

〈5.5〉 ネットワーク出力関数 制約条件の取扱いは 応答曲面を用いた最適化において最も重要な要素である。 はじめに述べたとおり，実験計画法を用いて応答曲面を作 成する場合，目的関数と制約条件を個別に二次近似してい るため, 応答曲面の最適解は実行可能領域内にある可能性 は低いと考えるべきである。そこで，制約条件をペナルテ イ関数として扱う方法が考えられるが，ペナルティ関数に おけるペナルティ係数の決定や更新方法には, 多くの試行 錯誤を要することが知られている( ${ }^{(8)}$ 。

そこで本論文では, 実行可能領域内にあるサンプル点に 対してはー1を, 実行可能領域外にあるサンプル点に対して は +1 を割当て, 実行可能性の有無を判別させる。そして, 実行可能領域内にあるサンプル点に対しては, 目的関数值 を反映するようネットワークに常にー 1 以下の数值を出力 させ，一方で実行可能領域外にあるサンプル点に対しては， 制約条件の違反量を反映させるよう常に +1 以上の数值を 出力させるネットワーク出力関数と称する関数を用いる。

サンプル点 $\boldsymbol{x}_{i} \quad(i=1,2, \cdots, p)$ に対し, ネットワーク出力 関数は次式にて与えられる。

$$
\begin{aligned}
& y_{i}=A \frac{\alpha_{i}+1}{2}\left(\frac{a_{i}-a_{\min }}{a_{\max }-a_{\min }}+\alpha_{i}\right) \\
& +B \frac{\alpha_{i}-1}{2}\left(\frac{f_{\max }-f_{i}}{f_{\max }-f_{\min }}-\alpha_{i}\right) . \\
& \text { ただし， } \\
& g_{j}\left(\boldsymbol{x}_{i}\right) \leq 0 \quad \forall j=1,2, \cdots, \text { ncon } \quad \rightarrow \alpha_{i}=-1 \\
& g_{j}\left(\boldsymbol{x}_{i}\right)>0 \quad \exists j \quad \rightarrow \alpha_{i}=+1 \cdots \\
& a_{i}=\sum_{j=1}^{n c o n} \max \left[0, g_{j}\left(\boldsymbol{x}_{i}\right)\right]
\end{aligned}
$$

ここで, (25)式の右辺第 1 項は制約条件に関する項であり, $a_{\max }$ と $a_{\min }$ はそれぞれ(28)式の最大值と最小值を表す。一 方, 右辺第 2 項は目的関数に関する項であり, $f_{i}$ は実行可 能領域内に存在するサンプル点 $\boldsymbol{x}_{i}$ の目的関数值を表し, $f_{\text {min }}$ と $f_{\text {max }}$ はそれぞれ, 実行可能領域内に存在するサンプル 点に対する目的関数の最小值と最大值を表す。また $A$ と $B$ は各項に対する重み係数である(ただし $A, B$ はともに 1 以 上の実数)。 
この式の意味であるが，(26)式および(27)式から実行可能 性を判断するパラメータ $\alpha_{i}$ により, すべてのサンプル点に 対する実行可能性の有無を判別する。 $i$ 番目のサンプル点が すべての制約条件を満足した場合，(25)式右辺 2 項のみが有 効となり, 目的関数值が正規化された状態でネットワーク の出力となる。一方, $i$ 番目のサンプル点がどれか一つでも 制約条件を満足しない場合, (25)式の右辺第 1 項のみが有効 となり,さらに(28)式より挙動制約条件の違反量がペナルテ イとして与えられ，ネットワークの出力として与えられる。 ネットワーク出力関数は結果的には制約条件を陰にペナル ティ関数として扱っていることになるが，通常のペナルテ イ法と比べたとき，ペナルティ係数の決定が必要ないとい う利点を含むと共に，目的関数值と制約条件值をそれぞれ 個別にネットワークの出力に反映させることができるとい う利点を有している。ネットワーク出力関数を用いて応答 曲面を作成すれば，側面制約条件と目的関数から構成され る事実上の無制約最適化問題を解くことに帰着されるた め, PSO の適用は妥当であると考える。

\section{6. 統合的最適化システムとその特徵}

本論文で提案する統合的最適化システムの流れを以下に 記述する。

(STEP1) 最大サンプル点数（関数評価回数）を決める。

（STEP2）サンプル点とその応答值から，ネットワーク出 力関数の計算。

（STEP3）RBF ネットワークによる応答曲面の構築。

（STEP4）PSO を用いた応答曲面の最適解の探索。

（STEP5）(22)式による応答曲面の最適解近傍の作成。

（STEP6）〈5・2〉節で述べた CASE1〜CASE4 に応じて, サ ンプル点を追加。

（STEP7）サンプル点数が最大サンプル点数以下なら STEP3 戻る。そうでなければ，終了。

なお提案システムでは, サンプル点数と中間層素子数 $(=$ 基底関数の数) は同じとしており, サンプル点の追加があ るごとに，基底関数も追加している。

本論文で提案する統合的最適化システムは以下の点で大 きな特徵を有している。

（1）過去のサンプル点情報をすべて活用できる点。

(2) 限られたサンプル点の中から, 近似最適解を見つけ ることができる点。

（3）精度の高い近似最適解を得るためには, どの辺りに サンプル点を追加すればよいのかを，自動的に提示できる 点。製品設計を考えた場合，今までは経験や勘に頼って行 われていたことが，系統的・定量的に行うことができる。 当然のことながら, 経験や勘といったものも, 数值化でき れば，サンプル点として追加できるため，極めて柔軟なシ ステム構成である。

(4) 実務レベルの最適設計では, 許容できる解析シミュ レーションもしくは実験回数は限られており, 少ない解析 シミュレーションもしくは実験の回数で精度の高い近似最
適解を求めたい場合は, (22)式の count の初期值を比較的大 きくとればよく, 一方で多くの解析シミュレーションもし くは実験回数が許される場合は, count の初期值は小さくと ればよい。設計者の意思と計算コストのバランスで任意に 設定できるパラメータ count を導入している。

\section{7. 数値計算例}

数值計算例を通じて, 提案する統合的最適化システムの 有効性を検証する。なお, 著者らの数值実験の経験に基づ いて, (25)式の $A$ と $B$ の設定は共に 10 とした。また(6)式 のパラメータ $\lambda_{j}$ は, 数值計算を通じて $\lambda_{j}=1.0 \times 10^{-3}$ とし,

(22)式の count の初期值は 1 とした。

$\langle 7 \cdot 1\rangle$ 多峰性関数最適化問題への適用 本論文で提 案した半径式の有効性を検討するため, 次の多峰性関数の 最小化問題を考える。

$$
\begin{aligned}
& f(\boldsymbol{x})=\frac{1}{2} \sum_{i=1}^{10}\left(x_{i}^{4}-16 x_{i}^{2}+5 x_{i}\right) \rightarrow \min \\
& -5 \leq \boldsymbol{x} \leq 5
\end{aligned}
$$

大域的最適解は $\boldsymbol{x}_{G}=(-2.9035,-2.9035, \cdots,-2.9035)^{T}$ であ り, 目的関数值は $f\left(x_{G}\right)=-391.661$ である。

この問題を 4 章で記述した PSO で直接的に求解した。探 索点数 (Particle 数) を 20 , 最大探索回数を 500 とし, 10 回 の試行を行った結果, 8 回は目的関数值および各設計変数值 の誤差が $0.1 \%$ 以下の精度で大域的最適解を見つけることが でき, 残りの 2 回は目的関数值がー 377.5200 となり, 次善 の局所的最適解を発見できた。表 1 に 10 回の試行の詳細な 結果を示す。なお表 1 の試行では, 探索過程における目的 関数值の評価は(29)式を用いて厳密に行っている。

一方，提案する統合的最適化システムでは，初期的に 50 のサンプル点をランダムに配置し, 最大サンプル点数（目 的関数の評価回数) を 400 点として, 大域的最適解の探索 を行った。サンプル点の追加数 $q$ は 5 である。なお, PSO の探索点数を 20 , 最大探索回数を 300 とした。(18)式を用い て 10 回試行したときの結果を表 2 に，また(13)式を用いて 10 回試行したときの結果を表 3 にそれぞれ示す。

なお表 2 および表 3 の各試行では, サンプル点に対して のみ(29)式を用いて目的関数值を評価し，これらのサンプル 点情報を用いて RBF ネットワークにより目的関数の応答曲 面を構築し, この応答曲面に対して PSO を適用し, 最適化 を行っている点に注意されたい。

表 2 より, 10 回試行した中で 1 回のみ近似大域的最適解 が得られているが, 残りの試行ではすべて次善の近似局所 的最適解が得られている。一方, 表 3 より, (13)式を用いた ときの結果は, 近似大域的最適解を見つけることができず, また近似局所的最適解の精度も悪いことがわかる。

以上のことから, 本論文で提案した(18)式の有効性が確認 できる。また, 提案したサンプル点配置方法が適切であっ たため, 比較的精度の高い次善の近似局所的最適解が得ら れたものと考えられる。さらに, 目的関数の評価回数 (Function call) としての計算コストは 20 分の 1 以下に軽減 
表 1 PSO による直接探索の結果

Table 1. The result of direct search by PSO

\begin{tabular}{|r|c|c|c|c|c|c|c|c|c|c|c|}
\hline Trial No. & $x_{1}$ & $x_{2}$ & $x_{3}$ & $x_{4}$ & $x_{5}$ & $x_{6}$ & $x_{7}$ & $x_{8}$ & $x_{9}$ & $x_{10}$ & obj. \\
\hline 1 & -2.9035 & -2.9035 & -2.9035 & -2.9035 & -2.9035 & -2.9035 & -2.9035 & -2.9035 & -2.9035 & -2.9035 & -391.6600 \\
\hline 2 & -2.9036 & -2.9036 & -2.9036 & -2.9035 & -2.9035 & -2.9035 & -2.9035 & 2.7468 & -2.9035 & -2.9035 & -377.5200 \\
\hline 3 & -2.9046 & -2.9027 & -2.9021 & -2.9038 & -2.9032 & -2.9047 & -2.9015 & -2.9043 & -2.9029 & -2.9049 & -391.6600 \\
\hline 4 & -2.9036 & -2.9035 & -2.9036 & -2.9036 & -2.9035 & -2.9035 & -2.9036 & -2.9035 & -2.9036 & -2.9036 & -391.6600 \\
\hline 5 & -2.9035 & -2.9035 & -2.9035 & -2.9035 & -2.9035 & -2.9035 & -2.9035 & -2.9035 & -2.9035 & -2.9035 & -391.6600 \\
\hline 6 & -2.9035 & -2.9035 & -2.9035 & -2.9035 & -2.9036 & -2.9035 & 2.7468 & -2.9036 & -2.9035 & -2.9035 & -377.5200 \\
\hline 7 & -2.9035 & -2.9035 & -2.9035 & -2.9035 & -2.9035 & -2.9035 & -2.9035 & -2.9035 & -2.9035 & -2.9035 & -391.6600 \\
\hline 8 & -2.9035 & -2.9035 & -2.9035 & -2.9035 & -2.9035 & -2.9035 & -2.9035 & -2.9035 & -2.9035 & -2.9035 & -391.6600 \\
\hline 9 & -2.9036 & -2.9034 & -2.9036 & -2.9036 & -2.9034 & -2.9036 & -2.9035 & -2.9035 & -2.9036 & -2.9036 & -391.6600 \\
\hline 10 & -2.9035 & -2.9035 & -2.9035 & -2.9035 & -2.9035 & -2.9035 & -2.9035 & -2.9035 & -2.9035 & -2.9035 & -391.6600 \\
\hline
\end{tabular}

\section{表 2 (18)式を用いたときの結果}

Table 2. The result using Eq. (18)

\begin{tabular}{|r|c|c|c|c|c|c|c|c|c|c|c|}
\hline Trial No. & $x_{1}$ & $x_{2}$ & $x_{3}$ & $x_{4}$ & $x_{5}$ & $x_{6}$ & $x_{7}$ & $x_{8}$ & $x_{9}$ & $x_{10}$ & obj. \\
\hline 1 & -2.7623 & -2.7805 & -2.7640 & -2.8303 & -2.9424 & -2.8213 & -2.8106 & -2.7930 & -2.8085 & -2.7635 & -389.7069 \\
\hline 2 & -2.8524 & -2.8425 & 2.6796 & -2.8160 & -2.7823 & -2.9739 & -2.7512 & -2.7777 & -2.8726 & -2.8843 & -378.1116 \\
\hline 3 & 2.7138 & -2.8840 & -2.8454 & -2.9078 & -2.8551 & -2.8602 & -2.8841 & -2.8358 & -2.8360 & -2.9336 & -377.1960 \\
\hline 4 & -2.8524 & -2.9185 & -2.8435 & 2.7837 & -2.8695 & -2.8336 & -2.8380 & -2.8282 & -2.8020 & -2.8518 & -376.9069 \\
\hline 5 & -2.8536 & -2.7847 & -2.9344 & -2.7463 & -2.8912 & -2.9147 & -2.7912 & 2.8028 & -2.8285 & -2.7898 & -376.2542 \\
\hline 6 & -2.8190 & -2.8861 & -2.8024 & -2.8897 & 2.6924 & -2.9117 & -2.7344 & -2.8194 & -2.7718 & -2.8310 & -376.2203 \\
\hline 7 & -2.8450 & 2.5675 & -2.7754 & -2.8766 & -2.9082 & -2.7117 & -2.8155 & -2.8464 & -2.8758 & -2.9087 & -375.9480 \\
\hline 8 & -2.8833 & -2.7546 & 2.6533 & -2.7995 & -2.8178 & -2.7881 & -2.8311 & -2.8475 & -2.7560 & -2.8093 & -375.8559 \\
\hline 9 & -2.9019 & -2.7840 & -2.8226 & -2.9112 & -2.7974 & -2.9385 & -2.8698 & 2.4440 & -2.8650 & -2.9299 & -375.7169 \\
\hline 10 & -2.8507 & -2.7236 & -2.8252 & -2.7762 & -2.8525 & 2.7506 & -2.7361 & -2.7757 & -2.9535 & -2.8264 & -375.6618 \\
\hline
\end{tabular}

\section{表 3 (13)式を用いたときの結果}

Table 3. The result using Eq. (13)

\begin{tabular}{|r|c|c|c|c|c|c|c|c|c|c|c|}
\hline Trial No. & \multicolumn{1}{|c|}{$x_{1}$} & \multicolumn{1}{|c|}{$x_{2}$} & $x_{3}$ & $x_{4}$ & $x_{5}$ & $x_{6}$ & $x_{7}$ & \multicolumn{1}{c|}{$x_{8}$} & $x_{9}$ & $x_{10}$ & obj. \\
\hline 1 & 1.5045 & -1.8374 & -1.8852 & -2.4623 & -1.5170 & -2.3714 & -2.7282 & -1.6251 & -2.7724 & -2.6230 & -292.6395 \\
\hline 2 & -1.5905 & -2.5437 & -2.8244 & -2.7952 & -1.7898 & 1.9684 & -2.3267 & 0.3350 & -3.6641 & -3.5344 & -271.4917 \\
\hline 3 & -2.1514 & 2.6340 & -1.7315 & -3.0507 & -2.6273 & 0.0400 & -1.9598 & 1.5126 & -2.7562 & -2.3907 & -271.3480 \\
\hline 4 & 0.8041 & -3.6182 & -2.5834 & -1.9136 & -2.8467 & 1.3314 & -1.1767 & -2.4806 & -2.3718 & -0.8407 & -236.5562 \\
\hline 5 & -3.0656 & -3.2653 & -0.2044 & -1.1958 & -2.0281 & -0.7261 & -2.3301 & -2.2350 & -2.0990 & -0.8688 & -231.2747 \\
\hline 6 & -2.6299 & -0.0391 & -3.0429 & -1.3986 & -2.9273 & -1.7380 & 1.4367 & -2.0069 & 1.9879 & -1.1464 & -228.5180 \\
\hline 7 & -2.3720 & 2.9123 & -0.1929 & -0.5237 & -0.7224 & -2.4464 & -2.7909 & -2.3716 & -0.9818 & -1.7721 & -214.2784 \\
\hline 8 & -3.5936 & -0.0851 & -1.7776 & -4.3128 & -2.5860 & -3.1855 & -2.8813 & -2.9421 & -0.3266 & 1.0602 & -201.4445 \\
\hline 9 & -3.3598 & -2.2500 & -0.1503 & -3.0571 & 2.2442 & -1.8064 & -2.5341 & -2.7056 & -2.8542 & -4.8294 & -196.3173 \\
\hline 10 & 0.8513 & 0.2513 & -1.8624 & 0.0213 & -1.7711 & -1.1894 & -1.0846 & -1.8482 & -2.0505 & 0.4015 & -135.2547 \\
\hline
\end{tabular}

できており，統合的最適化システムの有効性の一端を確認 することができる。

〈7·2〉 コイルの重量最小化問題＼cjkstart文献(15)のコイル バネの重量最小化問題を考える。設計変数はワイヤの直径 $d$, コイルの平均直径 $D$, コイルの巻数 $N$ であり, 図 8 のよ うに各設計変数を置き換えると, 最適設計問題は以下のよ うに定式化される。

$$
\begin{aligned}
& f(\boldsymbol{x})=\left(2+x_{3}\right) x_{1}^{2} x_{2} \rightarrow \min \\
& g_{1}(\boldsymbol{x})=1-\frac{x_{2}^{3} x_{3}}{71785 x_{1}^{4}} \leq 0 \\
& g_{2}(\boldsymbol{x})=\frac{4 x_{2}^{2}-x_{1} x_{2}}{12566\left(x_{2} x_{1}^{3}-x_{1}^{4}\right)}+\frac{1}{5108 x_{1}^{2}}-1 \leq 0
\end{aligned}
$$

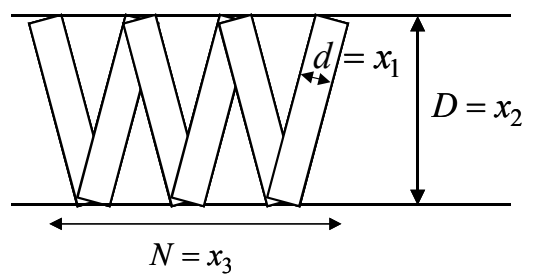

図 8 コイル重量の最適設計問題

Fig. 8. Optimum design of tension/compression spring

$$
\begin{aligned}
& g_{3}(\boldsymbol{x})=1-\frac{140.45 x_{1}}{x_{2}^{2} x_{3}} \leq 0 \\
& g_{4}(\boldsymbol{x})=\frac{x_{1}+x_{2}}{1.5}-1 \leq 0 \cdots
\end{aligned}
$$




\section{表 4 結果の比較}

Table 4. Comparison of results

\begin{tabular}{|l|l|l|l|l|c|}
\hline & Arora $^{(15)}$ & Coello $^{(17)}$ & Ray $^{(16)}$ & $\mathrm{Hu}^{(18)}$ & $\begin{array}{c}\text { This } \\
\text { research }\end{array}$ \\
\hline$x_{1}(d)$ & 0.053396 & 0.051480 & 0.050417 & 0.051466 & 0.055740 \\
\hline$x_{2}(D)$ & 0.399180 & 0.351661 & 0.321532 & 0.351384 & 0.428503 \\
\hline$x_{3}(N)$ & 9.185400 & 11.63220 & 13.979915 & 11.608659 & 8.971126 \\
\hline$g_{1}(\boldsymbol{x})$ & 0.000019 & -0.002080 & -0.001926 & -0.003336 & -0.018995 \\
\hline$g_{2}(\boldsymbol{x})$ & -0.000018 & -0.000110 & -0.012944 & -0.000110 & -0.061039 \\
\hline$g_{3}(\boldsymbol{x})$ & -4.123832 & -4.026318 & -3.899430 & -4.026318 & -3.752616 \\
\hline$g_{4}(\boldsymbol{x})$ & -0.698283 & -0.732123 & -0.752034 & -0.731324 & -0.677171 \\
\hline$f(\boldsymbol{x})$ & 0.012730 & 0.012705 & 0.013060 & 0.012667 & 0.014606 \\
\hline $\begin{array}{c}\text { Function } \\
\text { call }\end{array}$ & N/A & 900000 & 1291 & N/A & 86 \\
\hline $\begin{array}{c}\text { Average of } \\
f(\boldsymbol{x})\end{array}$ & N/A & 0.012769 & 0.013436 & 0.012719 & 0.016771 \\
\hline $\begin{array}{c}\text { Worst of } \\
f(\boldsymbol{x})\end{array}$ & N/A & 0.012822 & 0.013580 & N/A & 0.018438 \\
\hline
\end{tabular}

$0.05 \leq x_{1} \leq 2.00$

$0.25 \leq x_{2} \leq 1.30$

$2.00 \leq x_{3} \leq 15.0$

この最適化問題は高々 3 変数の問題であるが, 実行可能領 域内の最適解を見つけることが相当に困難な問題であるこ と, さらには多峰性が激しいため, 非常に多くの計算を必 要とすることが知られている(16)。そのため多点探索型最適 化手法のベンチマーク問題として，これまでにもよく用い られている(16) (18)。

本論文では，サンプル点の上限值を 150 とし，初期的に 側面制約条件内にランダムに 30 点のサンプル点を配置し た。サンプル点の追加数 $q$ は 2 である。なお, PSO のパラ メータは，探索点数を 30 , 最大探索回数を 200 とした。他 の代表的な研究結果と比較するため, 11 回試行に対する結 果を表 4 に示す。なお表 1 ，2，3 の試行と同様に，提案す る統合的最適化システム（This research）では，サンプル点 情報のみを用いて RBF ネットワークによりネットワーク出 力関数を用いて応答曲面を構築し，この応答曲面に最適化 を行っているのに対して，その他の手法では探索過程にお ける目的関数值の評価はすべて厳密に行っていることに注 意されたい。

表 4 より, 大域的最適解は得られなかったものの，従来 の研究報告に比べれば極めて少ない計算コスト（目的関数 の評価回数 : Function call) で近似局所的最適解を得られて おり，本論文で提案した統合的最適化システムの有効性の 一端を確認できたものと考えられる。

\section{8. おわりに}

本論文では最適化問題を直接的に解くのではなく, 関数 空間を近似する応答曲面を構築・更新しつつ, 近似最適解 を求めることで，解析シミュレーション回数もしくは実験 回数を激減させ得る新たな統合的最適化システムを提案し た。応答曲面構築に用いた RBF ネットワークでは，応答曲 面の精度に大きな影響を与える半径式について既存の式を 検討することにより，新たな半径式を提案した。またサン
プル点配置方法においては，局所的最適解への捕捉を防ぎ つつ, 精度の高い近似最適解を得られるような方法を提案 した。さらに制約条件の取扱いでは，ネットワーク出力関 数と称する判別関数を新たに提案し, 制約条件を含むより 一般的な最適化問題への適用を可能とした。

本論文は文献(1)で指摘された課題, 寸なわち統合的最適 化システムの構築という点を考慮した一つの解決策であ り, 実務レベルの重要な課題の一つである目的関数の評価 回数 (Function call) としての計算コストの軽減を実現した。 数值計算例では, 目的関数（評価関数）が設計変数の陽な 形で表現されている問題を扱ったが，実務レベルにおいて は目的関数を設計変数に関して陽に表すことが困難な場合 や，いくつかの実験データを直接用いて最適設計を行うこ とも多いため, 最適化の実用化の観点から観れば提案した 統合的最適化システムの有用性は高いと考えられる。

最後に，貴重な資料およびご意見をいただいた中山弘隆 先生 (甲南大学), 荒川雅生先生 (香川大学), 山川宏先生 (早稲田大学) に謝意を表する。

(平成 19 年 6 月 6 日受付, 平成 19 年 10 月 24 日再受付)

\section{文献}

(1) K. Fujita and T. Matsuo : "Survey and Analysis of Utilization of Tools and Methods in Product Development", Trans. of JSME, Vol.72-C, No.713, pp.290-297 (2006) (in Japanese)

藤田喜久雄・松尾崇宏 :「製品開発における手法やツールの活用状況 の調査と分析」, 日本機械学会論文集 C 編, 72, 713, pp.290-297 (2006)

(2) R. H. Myers and D. C. Montgomery : "Response Surface Methodology: Process and Product Optimization Using Designed Experiments", Wiley Interscience (1995)

(3) 山川 宏編 :「最適設計ハンドブック」, 朝倉書店, pp. 162-170 (2003)

(4) D. J. Joones, M. Schonlau, and W. J. Welch : "Efficient Global Optimization of Expensive Black-Box Functions", J. of Global Optimization, Vol.13, pp.455-492 (1998)

( 5 ) M. F. Hussain, R. R. Barton, and S. B. Joshi : "Metamodeling: Radial Basis Functions, versus Polynomials", European J. of Operational Research, Vol.138, pp.142-154 (2002)

(6) R. Jin, W. Chen, and T. W.Simpson : "Comparative Studies of Metamodelling Techniques under Multiple Modelling Criteria”, Structural and Multidisciplinary Optimization, Vol.23, pp.1-13 (2001)

(7) A. A. Mullur and A. Messac : "Extended Radial Basis Functions for Metamodeling: A Comparative Study", ASME/IDETC/CIE2005, Paper No. DETC2005-85041, in CD-ROM (2005)

（8）志水清孝:「システム最適化理論」, コロナ社 (1976)

(9) M. Maruyama : "Learning Networks Using Radial Basis Function - New Approach for The Neural Computing", Trans. of the Institute of Systems, Control, and Information Engineers, Vol.36, No.5, pp.322-329 (1992) (in Japanese)

丸山 稔:「Radial Basis Function を用いた学習ネットワーク 一ニュ 一ロコンピューティングに対する新しいアプローチ」, システム制御 情報学会論文誌, 36-5, pp.322-329 (1992)

(10) H. Nakayama, M. Arakawa, and R. Sasaki : "Simulation Based Optimization Using Computational Intelligence", Optimization and Engineering, Vol.3, pp.201-214 (2002)

(11) 坂和正敏・田中雅博 :「ニューロコンピューティング入門」, 森北出 版 (1997)

(12) M. J. L. Orr : "Introduction to Radial Basis Function Network", http://anc.ed.ac.uk/ mjo/rbf.html

(13) S. Haykin : "Neural Networks: A Comprehensive Foundation", Macmillan College Publishing Company, pp.236-284 (1994)

(14) S. Kitayama and K. Yasuda : "A Method for Mixed Integer Programming 
Problems by Particle Swarm Optimization", T. IEE Japan, Vol.125-C, No.5, pp.813-820 (2005) (in Japanese)

北山哲士・安田恵一郎 :「Particle Swarm Optimizationによる混合整数 計画問題の一解法」, 電学論, 125-C, 5, pp.813-820 (2005)

(15) J. S. Arora : "Introduction to Optimum Desig", McGraw-Hill, New York (1989)

(16) T. Ray and P. Saini : "Engineering Design Optimization Using Swarm with an Intelligent Information Sharing among Individuals", Engineering Optimization, Vol.33, pp.735-748 (2001)

(17) C. A. Coello Coello : "Use of a Self-Adaptive Penalty Approach for Engineering Optimization Problems", Computers in Industry, Vol.41, pp.113-127 (2000)

(18) X. H. Hu, R. C Eberhart, and Y. H. Shi : "Engineering Optimization with Particle Swarm”, IEEE Swarm Intelligence Symposium, pp.53-57 (2003)

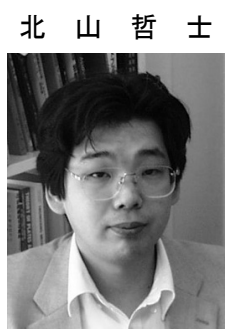

（正員） 2002 年 3 月早稲田大学大学院 理工学 研究科 機械工学専攻機械工学専門分野博士後 期課程退学。同年 4 月金沢大学工学部助手, 2005 年 10 月講師, 現在に至る。構造最適設計なら びに大域的最適化手法の開発・研究に従事。博 士 (工学)。

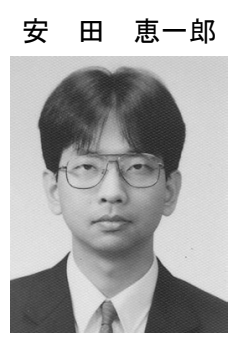

(正員) 1989 年 3 月北海道大学大学院 工学研 究科電気工学専攻博士課程修了。同年 4 月東京 都立大学工学部助手, 1991 年 4 月同大工学部助 教授。現在, 同大学大学院理工学研究科 教授。 システム最適化手法ならびに電力システム工 学の研究に従事。工学博士。

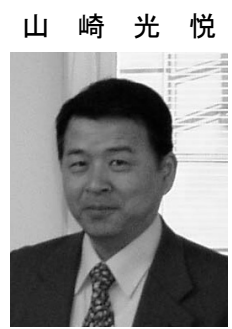

（非会員）1976 年 3 月金沢大学院工学研究科機 械工学専攻修士課程修了。1985 年 6 月金沢大学 工学部助教授, 1994 年 7 月同大工学部教授。現 在に至る。構造最適設計ならびに非線形応答を 伴う最適設計の研究に従事。工学博士。 